\title{
THE ROLE OF JUDGES IN THE DEVELOPMENT OF CONSTITUTIONS
}

\author{
Brice Dickson, School of Law, Queen's University Belfast*
}

\section{Introduction}

The debate about the role of judges in the British constitution has been prolific and fierce in recent years. It has, though, tended to focus too much on history and not enough on possible futures. It has concentrated on the 'is' and not on the 'ought'. And, like many debates, it has degenerated into one where there are basically two opposing camps, neither of which is prepared to give much ground to the other. There are a few outliers, but these too tend to squabble over their exact position vis-à-vis the other protagonists rather than rising above the fray and adopting a more positive frame of mind. What is needed is a more holistic approach, one which recognises that there are advantages in both main positions, as well as in their variants, but which prefers to focus not on whether judges are more important than law-making politicians in maintaining constitutionalism but on what steps each of those élites should take to copper-fasten the constitution against the vicissitudes of $21^{\text {st }}$ century living. Judges in most other countries do play a crucial role in developing their national constitutions. Judges in the UK have, on the whole, underperformed in that area, at least in the last few decades. Now is the time for them to raise their game.

The article begins by summarising the current debate. It then proceeds to review some of the contributions made by judges to constitutions elsewhere than in the United Kingdom. In its final section it makes and tries to justify ten suggestions as to how Britain's top judges should reform the British constitution. Throughout, the article takes a broad approach to the term 'constitution'. In particular it embraces within that term the rules and principles governing judicial freedom of action.

\section{The Current Debate}

In March 2004 Adam Tomkins delivered his inaugural lecture as the Professor of Public Law at the University of Glasgow, a lecture which he later expanded into book form. ${ }^{1}$ In this book he launched a passionate attack

* This is a version of my inaugural lecture, which was delivered under the same title at Queen's University Belfast on 27 April 2006. Although the overall thrust and main recommendations of the lecture have been maintained, there has been some slight restructuring and alteration of details. I am very grateful for comments made on a draft of the article by Dr Gordon Anthony. Remaining errors are, though, mine alone. I also wish to acknowledge more general indebtedness to Professor Desmond Greer, who was a wise and steady counsellor during my earlier employment at Queen's University from 1979 to 1991. I fear this article will not meet Des's high standards of scholarly rigour, which are legendary, but it is nonetheless dedicated to him with admiration and affection.

1 Adam Tomkins, Our Republican Constitution. For reviews see T. R. S. Allan [2006] P.L. 172; Ian Loveland (2006) 122 L.Q.R. 340; Danny Nicol (2006) 69 M.L.R. 280 
against those who advocate the theory known as 'common law constitutionalism' - the idea that at the core of the British constitutional order lies the common law made by judges. Tomkins opposes the views of commentators such as Jeffrey Jowell and Dawn Oliver at University College London and Paul Craig at Oxford. He had the temerity to undermine that guru of the common law, Ronald Dworkin. ${ }^{2}$ And he had a go, too, at Sir John Laws, the Court of Appeal judge who has extolled the virtues of the common law in extra-judicial writings ${ }^{3}$ as well as in his own judgments. ${ }^{4}$ Particular opprobrium, however, was reserved for Trevor Allan at Cambridge. ${ }^{5}$ Tomkins described Allan as a 'hardliner' and labelled the breadth of his support for constitutional justice as 'staggering'. To Allan, said Tomkins, 'it seems that there is no constitutional problem that is incapable of being solved by the courts and [that] no constitutional problem is solved until it is solved by the courts'. Tomkins thought this was 'legal constitutionalism at its most extreme'. ${ }^{6}$

Instead of relying upon the courts as the guardians of the constitution, Tomkins promotes the notion of 'political accountability'. Prior to acquiring his chair he had written articles defending what he called 'the political constitution', ${ }^{7}$ a throwback to the phrase used by John Griffith in the 1970s. ${ }^{8}$ In such works Tomkins has to some extent been following the lead given by Martin Loughlin at the London School of Economics and Political Science, in three books published since 1992. ${ }^{9}$ The reliance placed by Tomkins and Loughlin on the essentially political nature of the constitution is not so very far removed from the views of those who, like Christopher Forsyth and Mark

2 For Dworkin's latest defence of his position, see Justice in Robes.

3 'The Limitation of Human Rights' [1998] P.L. 62; 'The Constitution: Morals and Rights' [1996] P.L. 622; 'Law and Democracy' [1995] P.L. 80; 'Judicial Remedies and the Constitution' (1994) 57 M.L.R. 213; 'Is the High Court the Guardian of Fundamental Rights' [1993] P.L. 59. For John Griffith's views on these writings, see 'The Brave New World of Sir John Laws' (2000) 63 M.L.R. 159.

4 E.g. Thoburn v Sunderland City Council [2002] 3 WLR 247, criticised by Geoffrey Marshall in 'Metric Martyrs and Martyrdom by Henry VIII Clause' (2002) 118 L.Q.R. 493 but praised by Mark Elliott in 'Embracing "Constitutional" Legislation: Towards Fundamental Law? (2003) 54 N.I.L.Q. 25. Other prominent judicial advocates of common law constitutionalism include Sedley L.J. (see n.8 below), Lord Woolf (n.11 below), Lord Steyn (nn.78, 127 and 129 below) and Lord Cooke (see $\mathrm{n} .78$ below).

5 See, e.g. T. R. S. Allan, Law, Liberty and Justice: The Legal Foundations of British Constitutionalism and Constitutional Justice: A Liberal Theory of the Rule of Law.

6 Our Republican Constitution, n.1 above, p.20.

7 'In Defence of the Political Constitution' (2002) 22 O.J.L.S. 157.

8 'The Political Constitution' (1979) 42 M.L.R. 1. Tomkins discusses this article in Our Republican Constitution, n.1 above, at pp.36-38. See too John Griffith, The Politics of the Judiciary, first published in 1977 but now in its $5^{\text {th }}$ edition (1997); 'The Common Law and the Political Constitution' (2001) 117 L.Q.R. 42; 'Judicial Decision-Making in Public Law' [1985] P.L. 564. Also Sir Stephen Sedley, 'The Sound of Silence: Constitutional Law without a Constitution' (1994) 110 L.Q.R. 270 and 'The Common Law and the Political Constitution: A Reply' (2001) 117 L.Q.R. 68 .

9 Public Law and Political Theory; Sword and Scales: An Examination of the Relationship between Law and Politics; The Idea of Public Law. 
Elliott at Cambridge, ${ }^{10}$ still maintain the rather Diceyean line that all judicial development of the law must ultimately be traced back to the supposed intention of Parliament. Tomkins' approach has to some extent been bolstered by the likes of Thomas Poole, who claims that common law constitutionalism fails to adequately explain the main features of the way judicial review actually operates in Britain. ${ }^{11}$ Poole sees judges as aristocrats and moral imperialists. ${ }^{12}$ Another lawyer at Glasgow, Gavin Anderson, makes three further criticisms of common law constitutionalism (or, rather, of what he calls 'rights constitutionalism'): he believes that it fails to control private, as opposed to public, power; it ignores the significance of the practices and actors of the global economy; and it considerably overstates the capacity of judges to be coherently instrumental. ${ }^{13}$ In Anderson's words, 'judges, like other law-creating subjects, construct distinctive personal accounts of the legal world, whose mutual interaction necessarily leads to inconsistency and contradiction'. ${ }^{14}$

Not surprisingly, well-known attempts have been made to pigeon-hole those who write in this area by giving them fancy labels. Martin Loughlin describes people who place great emphasis on the work of the courts as 'conservative normativists'; those who prefer to place their trust in Parliament and in politics, Loughlin calls 'functionalists'. ${ }^{15} \mathrm{He}$ reserves a third label for people who believe that courts should not have the final say over everything but should at least articulate principles which can guide the executive in the exercise of its discretions. This category should, I think, embrace people like Sir William Wade (that much-lamented icon of British constitutional law who died in $2005^{16}$ ), Robert Stevens (still writing about British judges 50 years after his first article was published ${ }^{17}$ ) and Sir Neil MacCormick, the eminent legal philosopher at Edinburgh whose latest book, Rhetoric and the Rule of Law, provides many insights into the nature of

10 See, e.g. 'Of Fig Leaves and Fairy Tales: The Ultra Vires Doctrine, the Sovereignty of Parliament and Judicial Review' (1996) 55 C.L.J. 122.

11 'Questioning Common Law Constitutionalism' (2005) 25 L.S. 142. See too his 'Back to the Future? Unearthing the Theory of Common Law Constitutionalism' (2003) 23 O.J.L.S. 435; and 'Harnessing the Power of the Past? Lord Hoffmann and the Belmarsh Detainees Case' (2005) 32 J.L.S. 534. See also Lord Woolf, 'Judicial Review - The Tensions Between the Executive and the Judiciary' (1998) 114 L.Q.R. 579 and 'European Court of Human Rights on the Occasion of the Opening of the Judicial Year' [2003] E.H.R.L.R. 257. Danny Nicol (n.1 above, at p.284) praises Tomkins for 'swimming against the tide of judicialisation'.

12 Thomas Poole, 'Dogmatic Liberalism? T R S Allan and the Common Law Constitution' (2002) 65 M.L.R. 463 at 474-5.

13 Constitutional Rights after Globalization. Anderson uses the term 'rights constitutionalism' rather than 'common law constitutionalism', but there appears to be little difference between them. At p.4 he certainly favours 'legal pluralism' as the explanatory paradigm for constitutionalism: '[L]egal pluralism reveals the political character of our prevailing definitions of constitutionalism and demonstrates how state-centred accounts prevent us from asking questions of accountability with regard to all forms of political power'.

14 ibid., p.146. Anderson's prefers to rely on a theory which he calls 'legal pluralism'.

15 Martin Loughlin, Public Law and Political Theory, chs. 7 and 8.

16 See, especially, Constitutional Fundamentals.

17 See, especially, The English Judges: Their Role in the Changing Constitution. 
judicial reasoning. These people, in Loughlin's terms, are 'liberal normativists'. If, like me, you have an in-built aversion to such grandiose labels you might prefer the much more prosaic categories suggested by Carol Harlow and Richard Rawlings, who simply talk of red-light and green-light approaches. ${ }^{18}$

My own approach lies somewhere between red and amber. In Loughlin's terms I'd be a 'liberal-conservative normativist'. This means that, in my view, judges can and should play a very significant role in shaping constitutions. They should actively seek to control both the government and Parliament, preventing those institutions from damaging the rule of law and the separation of powers. There should be very few issues which are nonjusticiable. At the same time, the power of judges should not be unbridled. The judiciary should be just one site in which sovereignty is located. Power must also reside in other sites, ${ }^{19}$ and values other than legal ones must be promoted. But judges bring relative detachment, valuable experience and absolute integrity to their work. We should, therefore, give them a fairly free rein. ${ }^{20}$ We should not, I think, adopt the approach of Horace Walpole, who in 1770 wrote in a letter: 'Everybody talks of the constitution, but all sides forget that the constitution actually works extremely well, if they would let it alone'. ${ }^{21}$ Letting it alone should not be considered an option today. ${ }^{22}$

In any event, the critics of common law constitutionalism tend to ignore some important 'modern' features of the British legal system. For a start, they do not generally respect the influence of European institutions. Anyone wishing to remind themselves of that influence should consult the writings of Nicholas Bamforth. ${ }^{23}$ He brings a dose of realism to the debate by observing that no theory about today's UK constitution can be valid unless it explains why a British court will 'disapply' an Act of Parliament if it is inconsistent with EC law or why, as a result of the Human Rights Act, courts are free to disagree with Parliament - not just with government - that a piece of primary legislation is compatible with the European Convention on Human Rights. Bamforth endorses what Gordon Anthony usefully describes as the 'spillover' effect - the idea that courts in the UK are influenced by European considerations even though the specific matter at issue is not regulated by EC

18 Law and Administration (2 ${ }^{\text {nd }}$ ed., 1997), chs. 2 and 3.

19 Anthony Sampson believes it partly lies in Radio Four's Today programme: see Who Runs This Place? The Anatomy of Britain in the $21^{\text {st }}$ Century, pp.222-227. Sedley LJ has argued for 'bi-polar sovereignty': see 'Human Rights: A Twentyfirst Century Agenda' [1995] P.L. 386, 389.

20 I have a lot of empathy with the views expressed by Daniek Farber and Suzanna Sherry in Desperately Seeking Certainty: The Misguided Quest for Constitutional Foundations.

21 Letter to Sir Horace Mann, 18-19 January 1770.

22 Cf. Lord Bingham in 'The Courts and the Constitution' (1996-97) 7 King's College Law Journal 12, reprinted in The Business of Judging: Selected Essays and Speeches; pp.225-238, who said (at p.237 of the latter): 'Constitutional arrangements, like motor cars, require periodic inspection and overhaul, so that worn-out parts may be renewed and ill-fitting parts adjusted. The fact that a constitution such as ours has been on the road for a very long time makes this attention more necessary, not less'.

23 Especially 'Courts in a Multi-Layered Constitution', in Nicholas Bamforth and Peter Leyland (eds.), Public Law in a Multi-Layered Constitution, ch.11. 
law or the Convention. ${ }^{24}$ The main message coming from Bamforth's and Anthony's analyses, with which I agree, is that reports of the death of common law constitutionalism are greatly exaggerated.

And if such reports were exaggerated three or four years ago, they are even more so today because in the last few years there has been a renaissance of interest in the rule of law on the part of our top judges, the Law Lords. Those judges are, of course, about to metamorphose into Justices of the UK's Supreme Court, ${ }^{25}$ although not, it seems, before October $2009 .{ }^{26}$ When that occurs, their role as guardians of our constitution will surely become even more obvious. $^{27}$ As it is, Law Lords are already standing their ground against New Labour's increasing authoritarianism. ${ }^{28}$ Their two recent decisions on the position of foreign detainees at Belmarsh prison are, it is to be hoped, not just straws in the wind but emblems of a whole new spirit of judicial activism. ${ }^{29}$ At the end of 2004 eight Law Lords ruled that internment without trial under the Anti-terrorism, Crime and Security Act 2001 was contrary to the European Convention's guarantee of the right not to be deprived of liberty on a discriminatory or disproportionate basis. ${ }^{30}$ They measured the Act against Article 15 of the Convention, which is not one of the articles incorporated by the Human Rights Act, so this is a further example of Anthony's 'spill-over' effect. A year later a unanimous bench of seven Law Lords ruled that no British court can rely upon evidence that may have been obtained anywhere in the world through the use of torture. ${ }^{31}$

A close reading of the judgments in both those cases could surely leave noone in any doubt that the highest court in the land plays an absolutely crucial

24 Gordon Anthony, UK Public Law and European Law: The Dynamics of Legal Integration.

25 Constitutional Reform Act 2005, ss.23-60.

26 Statement by the Lord Chancellor, Lord Falconer, on 1 March 2006: www.dca.gov.uk/pubs/ statements/2006/st060301b.htm.

27 The Constitutional Reform Act 2005, which creates the Supreme Court, states in s.1(a) that the Act 'does not adversely affect the existing constitutional principle of the rule of law'.

28 For a recent journalistic blast at New Labour see Henry Porter, 'Only a constitution can save us from this abuse of power', The Observer, 2 April 2006.

29 Cf. Secretary of State for the Home Department v MB (12 April 2006), where Sullivan J held that s.3(10) of the Prevention of Terrorism Act 2005 did not give the respondent the fair hearing he was entitled to under the Human Rights Act 1998 because (in the judge's view) it confined the court to looking only at the onesided material available to the Secretary of State at the time the order was made. The judge said that the thin veneer of legality which was sought to be applied by s 3 of the 2005 Act could not disguise the reality that the Convention rights of people subjected to control orders were being determined not by an independent court but by executive decision-making untrammelled by any prospect of effective judicial supervision. As it was not possible for the court to conclude that the Secretary of State's decisions were legally flawed upon the basis of the one-sided information then available to him, the control order had to continue in force but $\mathrm{s}$. $3(10)$ was declared to be incompatible with Convention rights.

30 A v Secretary of State for the Home Department [2005] 2 A.C. 68. Lord Walker dissented. Lord Bingham's judgment in this case was to some extent presaged by his Romanes lecture delivered on 15 October 2002 and published as 'Personal Freedom and the Dilemma of Democracies' (2003) 52 I.C.L.Q. 841

31 A v Secretary of State for the Home Department (No.2) [2006] 1 All E.R. 575. 
role not just in protecting human rights but in curbing the excesses of Parliament and the executive. Yet in his comments on the first of these decisions, Adam Tomkins damns with faint praise. ${ }^{32}$ He claims that the Law Lords were 'merely following a path already broken by others' and that 'the change of tone ... should not mislead us into thinking that it heralds a change of approach'. His justification for this view is that after the judgments were issued the Belmarsh detainees were still in prison and the rest of the Anti-terrorism Act was still on the statute book. He seems to be saying that unless judges can completely usurp the functions of elected politicians they are entirely useless. To adapt his own phrase, this is surely republicanism at its most extreme.

To appreciate better the contribution judges could and should make to the UK's constitution one needs to look abroad. ${ }^{33}$ The next section of this article will conduct a brief survey of some leading liberal democracies to see what innovations could possibly be mirrored in Britain.

\section{Contributions to Constitutionalism Made by Judges Elsewhere}

The American Constitution, one often reads, is be applauded for the way it permits the Supreme Court to invalidate Acts of Congress if they are 'unconstitutional'. But of course that power was not conferred by the 1787 document signed by George Washington and others, nor by the first 10 amendments which were agreed in 1791 and which we call the Bill of Rights. Instead, the power was created for itself by the US Supreme Court. In Marbury v Madison, ${ }^{34}$ in 1803, Chief Justice Marshall skilfully gave President Jefferson the result he was hoping for by holding that the attempt by the previous President, John Adams, to appoint a number of federal judges before he left office, was ineffective. This was because the Act of Congress $^{35}$ authorising the Court to enforce the appointments was held not to be valid. Under Article III of the Constitution the Court had been given a number of specific functions and without express authorisation Congress had tried to expand those functions. Very cleverly the Court denied to itself the lesser power to enforce judicial appointments but in the very act of doing so conferred on itself the much greater power to declare Acts of Congress to be unconstitutional.

It is on this slender foundation that the whole edifice of judicial review in America has subsequently been constructed, although instances of Acts being declared unconstitutional remain rare. It did occur when Franklin Roosevelt was pursuing his New Deal ideology in the 1930s, and the Supreme Court's stance on that occasion is sometimes taken, wrongly I

32 'Readings of A v Secretary of State for the Home Department' [2005] P.L. 259.

33 For a useful comparison of constitutionalism in the UK, the US, France and Germany see Tim Koopmans, Courts and Political Institutions ; and for specific information on comparativism in the human rights field see Christopher McCrudden, 'A Common Law of Human Rights? Transnational Judicial Conversations on Constitutional Rights' (2000) 20 O.J.L.S. 499.

34 (1803) 1 Cranch 137; 5 U.S. 137. See William Nelson, Marbury v Madison: The Origins and Legacy of Judicial Review, reviewed by J O'Neill, 'Marbury v Madison at 200: Revisionist Scholarship and the Legitimacy of American Judicial Review' (2002) 65 M.L.R. 792

35 The Judiciary Act 1789. 
think, as an illustration of judicial opposition in America to the notion of social and economic rights. ${ }^{36}$ The truth is that the New Deal case turned on a different point altogether, namely on whether Congress had delegated too much power to an administrative agency without giving it adequate guidance on how to exercise that power. If anything, therefore, the decision was a blow in favour of constitutionalism and a few years later the Supreme Court had little difficulty in upholding different New Deal legislation which was more clearly drafted. ${ }^{37}$

But it is worth noting that in recent years considerable scepticism has been voiced in America about the current Supreme Court's commitment to constitutionalism. Disdain for judges' constitutional work has been displayed, for example, by Mark Tushnet of Georgetown Law School, in books with provocative titles such as The New Constitutional Order and Taking the Constitution Away from the Courts, where he argues that the credit usually accorded to the US Supreme Court for maintaining the rule of law is grossly overestimated. Others have taken up the same theme. Robert Bork, whose nomination to the Supreme Court by President Reagan was vetoed by the Senate in 1987 , recently published a book condemning what he calls 'the world-wide rule of judges'. ${ }^{38}$ Mark Levin, likewise, has written a study entitled Men in Black: How the Supreme Court is Destroying America. And Jeremy Waldron, a New Zealander now based in New York, maintains the same line. ${ }^{39}$ Some legal academics are less sweeping in their condemnation, but in the lead-up to the not unexpected death of Chief Justice Rehnquist in 2005, and in the commentaries on the appointment of John Roberts as his successor, there have been numerous negative assessments of how little the US Supreme Court has contributed to constitutionalism in recent times. ${ }^{40}$ Its somewhat half-hearted efforts to control the American government's excesses during the current 'war on terror' are, to many, symptomatic of the malaise. ${ }^{41}$ If the UK's judges are failing to rise to constitutional challenges, it seems that American judges, despite having a much greater tradition in the field, and more 'weapons' at their disposal, are also in need of strong encouragement to be more active.

In America the review of the constitutionality of primary legislation can occur only after it has been enacted. In France it can occur only beforehand. The Constitution of the Fifth Republic, in place since 1958, created a body

36 Schecter Poultry Corp v United States (1935) 295 U.S. 495.

37 Yakus v United States (1944) 321 U.S. 414.

38 Coercing Virtue: The World-wide Rule of Judges.

39 See e.g. Law and Disagreement.

40 See, e.g. Herman Schwartz (ed.), The Rehnquist Court. For a more generous view see Thomas Keck, The Most Activist Supreme Court in History, esp. Part III ('The Rehnquist Court and the Splintering of Judicial Conservatism, 1994-2003').

41 But see Tim Otty and Ben Olbourne, "The US Supreme Court and the "War on Terror": Rasul and Hamdi' [2004] E.H.R.L.R. 558, where the authors say (at p.569) that in these two decisions the Court underscored in the strongest possible fashion the importance of the individual's right to liberty and affirmed the rule of law. The US Supreme Court's unwillingness to look abroad for guidance has also been much lamented; see, e.g. Cherie Booth and Max du Plessis, 'Home Alone? The US Supreme Court and International and Transnational Judicial Learning' [2005] E.H.R.L.R. 127. 
known as the Constitutional Council (Le Conseil constitutionnel) ${ }^{42}$ This body is not actually a court at all and its nine members are not judges, but one of its functions is to examine draft statutes (lois) to see if they conform with the Constitution. The Councillors do not read or listen to arguments put by advocates for the opposing points of view. They do their own thinking, taking account only of documents preceding the draft law and of the French Constitution itself. But they have been adept at reading into that Constitution additional criteria for assessing whether laws are in conformity with it.

The turning point came in 1971. A year earlier the French Cabinet had ordered the dissolution of a small left-wing political party, La Gauche Prolétarienne. In response to this, activists such as Jean-Paul Sartre and Simone de Beauvoir set up another group named after the newspaper of the banned party, La Cause du Peuple. The government directed the local prefect not to register this new group but a local administrative court rather bravely ruled that the prefect had no such power to refuse registration. The government then introduced a Bill to widen the prefect's powers and it was this Bill which the Constitutional Council struck down. It did so by implying into the Constitution the so-called 'fundamental principles recognised by the laws of the Republic', a phrase mentioned in the Preamble to the 1946 Constitution of the Fourth French Republic and deemed to be affirmed by the Preamble to the 1958 Constitution. ${ }^{43}$ One of these principles, said the Council, was that of freedom of association. And it is on the back of that momentous decision that the Constitutional Council has since built an envious reputation for guaranteeing civil liberties in France. Last year the Council pronounced on 18 draft laws. This year it has already invalidated parts of the proposed anti-terrorism law, ${ }^{44}$ although it upheld the controversial youth employment law, which was found not to be in breach of the principle of equality. ${ }^{45}$ Of course, political and popular pressure later conspired to force President Chirac to suspend that law, a move which prompted a recent commentator to suggest that the ritual of mass protests reversing unpopular governmental measures should actually be regarded as an informal part of the French constitution. ${ }^{46}$

The French Council has another important function - the supervision of elections. That responsibility also fell to the US Supreme Court when Al Gore challenged the electoral victory of George W Bush in 2000. The Court split 5 to 4 in favour of not permitting any further recounting of the votes in Florida, thereby handing the presidency to Mr Bush. ${ }^{47}$ Analysts usually observe that there was an uncanny alignment between the supposed political views of the nine US justices and the ultimate outcome of the case, but

42 Arts. 56-63. For more details see Brice Dickson, Introduction to French Law, pp.52-53 and pp.85-89.

43 Although technically the Preamble to the 1958 Constitution refers only to the human rights and principles of national sovereignty defined by the 1789 Declaration of the Rights of Man and confirmed and supplemented by the Preamble to the 1946 Constitution.

44 Decision no. 2006-532 D.C. (19 January 2006).

45 Decision no. 2006-535 D.C. (30 March 2006).

46 Robert Tombs in The Times Higher Education Supplement, 21 April 2006, p.17.

47 Bush v Gore (2000) 531 U.S. 98. See E J Dionne and William Kristol (eds), Bush v Gore: The Court Cases and the Commentary. 
whether any of the judges actually allowed their personal political predilections to influence their voting is impossible to verify. Their political predilections could have been the result of, rather than the cause of, their conception of the role of judges in developing the constitution. Adam Tomkins condemned this case as another lamentable example of unhelpful judicial interference in constitutional affairs, ${ }^{48}$ he would therefore also have to condemn the involvement of the Corte di Cassazione in Italy when, in April 2006, it confirmed the electoral victory of Romano Prodi. As we know from the experience of Germany last year and Iraq this year, courts may not be able to force politicians into coalitions, but they can at least determine who won most votes at an election. If a top court is not the right body to decide that, who is? And, by the way, according to opinion polls, the reputation of the American Supreme Court hardly suffered at all as a result of its intervention in Bush v Gore. ${ }^{49}$

The American Court has also been active in developing 'unenumerated' constitutional rights - rights which are not expressly mentioned in the Constitution, but which judges see as implicit. But we do not need to cross the Atlantic, or even the English Channel, to encounter judges who are prepared to invent such rights. Just down the road is a jurisdiction where the Supreme Court has been remarkably active in doing just that. Ireland even allows its judges to assess the constitutionality of legislation either before or after its enactment. ${ }^{50}$ One of the unenumerated rights in Ireland is the right to privacy. The others include the right to strike, the right to earn a living, the right to communicate, the right to access the courts, the right to be legally represented if facing criminal charges, the right to protection of one's health, the right to travel, the right to found a family and the right to know the identity of one's natural mother. All of these rights are creations of the common law. ${ }^{51}$ Not everyone is a fan of how the Irish judges have gone about their task - David Gwynn Morgan at Cork, for example, is critical of

48 "In defence of the Political Constitution" (2002) 22 O.J.L.S. 157 at 170.

49 Just before the 2000 election an opinion poll suggested that $62 \%$ of the American public approved of the way the Supreme Court was handling its job, with only $25 \%$ disapproving. Surprisingly, the approval rate amongst Democrats was $10 \%$ higher than amongst Republicans [70\% to $60 \%$ ]. Immediately after the Court's decision in Bush v Gore approval ratings dropped by $3 \%$ and disapproval ratings rose by $9 \%$. The approval rate amongst Democrats was now $38 \%$ less than amongst Republicans. But a few months later, in June 2001, the overall approval and disapproval figures were back to what they had been pre-election and the differential between Democrats and Republicans had been reduced from 38\% to $22 \%$. And independent voters were more approving of the Supreme Court than they had been prior to the election [59\% to 57\%]. These statistics are taken from Robert McCloskey (rev. by Sanford Levinson), The American Supreme Court (4 $4^{\text {th }}$ ed., 2005), pp.177-178.

50 But not on both occasions. Art. 34.3 .3 provides: 'No Court whatever shall have jurisdiction to question the validity of a law, or any provision of a law, the Bill for which shall have been referred to the Supreme Court by the President under Article 26 of this Constitution, or to question the validity of a provision of a law where the corresponding provision in the Bill for such law shall have been referred to the Supreme Court by the President under the said Article 26'. This provision is described by James Casey as a 'serious disadvantage': see his Constitutional Law in Ireland ( $3^{\text {rd }}$ ed., 2000), at p.338.

51 James Casey, ibid., pp.394-433. 
their inconsistency and of their reliance on principles which to him are not rational. ${ }^{52}$ Furthermore, in the last few years a marked conservatism has become evident within the Irish Supreme Court. ${ }^{53}$ Worrying examples are the case of Jamie Sinnott, a young autistic man who was, in effect, denied the right to education, ${ }^{54}$ and the case of $T D,{ }^{55}$ where only one judge, Mrs Justice Denham, was bold enough to order the government to provide support units for teenagers with behavioural difficulties - the other judges saw that as a step too far for the judiciary, a step that would breach the doctrine of separation of powers by allowing judges to do what was supposedly the preserve of Dáil Éireann.

In this respect the Irish Supreme Court has not followed the lead of the Supreme Court of India, which has come under attack not for being judicially inactive but for being judicially over-active. It has been particularly imaginative in developing the right to life and personal liberty, which is guaranteed by Article 21 of the Indian Constitution of 1950 but which, thanks to the Supreme Court, now embraces as well the right to shelter, the right to health, the right to work, the right to clean air and clean water and the right to information. In a recent case brought by a journalist, the Indian Supreme Court relied on the right to equality in Article 14 of the Constitution to order criminal justice agencies to investigate the alleged financing of terrorist organisations by high-ranking politicians. ${ }^{56}$ This prompted one critic to remark that what was formerly judicial activism had evolved into judicial arrogance ${ }^{57}$ and he warned that, unless the Supreme Court exercises restraint, 'the activist profile may be the first footprints of an impending constitutional lawlessness in India'.58

Well, maybe the Indian court has gone too far, and maybe the Irish court is wise to be cautious. But in the UK judges are a long way from reaching those outer limits of constitutional activism. And they have far to go before coming anywhere near the role played by the Constitutional Court of South Africa or, in recent years, by the Supreme Court of Canada, although those courts do benefit from having very modern constitutional documents from which to work. It was apparent from its earliest judgments in the mid$1990 \mathrm{~s}^{59}$ that the South African Court was going to be one which grounded its decisions in a purposive interpretation of the country's Constitution, which came to its conclusions only after considering how courts in other parts of the world - and not just courts based on the Anglo-Saxon model - had

52 'Judicial Activism - Too Much of a Good Thing' in Tim Murphy and Patrick Twomey (eds.), Ireland's Evolving Constitution, 1937-97: Collected Essays, ch 9.

53 I wish to acknowledge assistance provided by Rossa Fanning of U.C.D. in this area.

54 Sinnott v Minister for Education [2001] 2 I.R. 545.

$55 T D$ v Minister for Education [2001] 4 I.R. 259.

56 Vineet Narain v Union of India [1998] A.I.R. S.C. 889.

57 Shubhankar Dam, 'Vineet Narain v Union of India: "A Court of Law and not Justice" - Is the Indian Supreme Court beyond the Indian Constitution?' [2005] P.L. 239 at p.247.

58 ibid., p.241. For a less worried perspective see S.P. Sathe, Judicial Activism in India: Transgressing Borders and Enforcing Limits.

59 'Protecting Human Rights Through a Constitutional Court: The Case of South Africa' (1997) 66 Fordham Law Review 531. The Court heard its first case in 1995. 
resolved similar issues, and which contained judges who couched their judgments not in vapid legal jargon but in inspirational phrases. ${ }^{60}$ The Court has also been refreshingly pragmatic, best illustrated perhaps in its use of the power to suspend the invalidation of legislation until the government has had a reasonable time to amend it. $^{61}$ This is a power which the Federal Constitutional Court of Germany has also conferred upon itself. ${ }^{62}$ And the South African Court has pronounced at length on the scope of social and economic rights, yet without usurping the mandate of elected politicians in that domain. ${ }^{63}$

Canada, too, has benefited from having a Supreme Court that is imaginative and internationalist in its outlook, although in the view of one commentator, there is 'no set of judges in the developed world who are treated by the general population with such glowering suspicion'. ${ }^{64}$ My colleague Rory O'Connell has made a special study of the 'political' role of the court ${ }^{65}$ and is currently analysing how it has innovatively developed the concept of equality. The leading Canadian scholar in this field, Kent Roach, has shown in his book The Supreme Court on Trial, that 'an independent and courageous judiciary is the best institution we have to remind us of' the effects of our actions on the unpopular and the disadvantaged. ${ }^{66}$ One of the numerous decisions Roach highlights ${ }^{67}$ is that where the Supreme Court read into the human rights code of Alberta the right not be discriminated against

60 Arthur Chaskalson and Albie Sachs have been particularly to the fore in this regard.

61 S.172(1) of the Constitution of South Africa 1996 (formerly s.98(5) of the Interim Constitution 1994): 'When deciding a constitutional matter within its power, a court (a) must declare that any law or conduct that is inconsistent with the Constitution is invalid to the extent of its inconsistency; and (b) may make any order that is just and equitable, including (i) an order limiting the retrospective effect of the declaration of invalidity; and (ii) an order suspending the declaration of invalidity for any period and on any conditions, to allow the competent authority to correct the defect'. The power to suspend a declaration of invalidity was first exercised in $S$ v Ntuli 1996 (1) S.A.L.R. 1207, where the government was given some 16 months to produce corrective legislation. This deadline was later extended but ultimately the Constitutional Court held that the Minister's officials had failed to act promptly and diligently and that the order of invalidity must therefore stand: Minister of Justice v Ntuli (5 June 1997).

62 Lars Mammen, 'A Short Note on the German Federal Constitutional Court and its Power to Review Legislation' [2001] E.H.R.L.R. 433.

63 Most notably in Republic of South Africa v Grootboom 2000 (1) S.A. 46. See also Ivan Hare, 'Minister of Health $\mathrm{v}$ Treatment Action Campaign: The South African AIDS Pandemic and the Right to Healthcare' [2002] E.H.R.L.R. 624.

64 M. A. Sanderson, reviewing K. Roach, The Supreme Court on Trial (2003) 52 I.C.L.Q. 542 at 543.

65 Legal Theory in the Crucible of Constitutional Justice: A Study of Judges and Political Morality in Canada, Ireland and Italy.

66 Preface, p.ix.

67 ibid., pp.195-6. See too $M \vee H$ [1999] 2 S.C.R. 3, where the Court held that the exclusion of same-sex common law partnerships from the support provisions in Ontario's Family Law Act 1990 was unjustified discrimination against gays and lesbians. That case was cited to the Law Lords, although not relied upon in their judgments, in Ghaidan v Godin-Mendoza [2004] 2 A.C. 557. 
on the basis of sexual orientation, even though the legislature had deliberately omitted that right. ${ }^{68}$

So, all over the world top courts have deployed considerable imagination in developing their national constitutions. And frequently they have achieved this without relying upon the specific wording of their constitution. New Zealand, like Britain, does not have a written constitution, but that has not stopped the highest court there from ruling that people should be compensated if their fundamental human rights are breached. ${ }^{69}$ It is worth remembering, too, that international courts play an ever more important role in promoting constitutionalism. Some would say that the European Court of Justice, like the Indian Supreme Court, has been a little too enthusiastic in doing just that. ${ }^{70}$ Steven Greer, at Bristol, argues that the European Court of Human Rights has devised both primary and secondary constitutional principles to guide its own adjudication processes. ${ }^{71}$ Certainly that Court has judged important constitutional issues arising within Britain. It has ruled that it is not contrary to basic democratic principles to allow members of Parliament to be immune from being sued for whatever they say in Parliament. ${ }^{72}$ It has also insisted, in a case that came from Guernsey, that judicial power must be wielded completely separately from executive or legislative power, ${ }^{73}$ a decision which prompted the British Lord Chancellor to announce that he would no longer sit as a judge. And in what seems to me a less impressive decision, the European Court upheld the quaint rule that no-

68 Vriend v Alberta (1998) 156 D.L.R. $4^{\text {th }} 385$.

69 See Simpson v Attorney-General [1994] 3 N.Z.L.R. 667. Appeals against the New Zealand Court of Appeal used to go to the Judicial Committee of the Privy Council in London. From 2004 they have gone to the new Supreme Court of New Zealand: see the Supreme Court Act 2003 (N.Z.).

70 H. Rasmussen, On Law and Policy in the European Court of Justice: A Comparative Study in Judicial Lawmaking. For a more recent playing out of the debate see T. Hartley, 'The European Court, Judicial Objectivity and the Constitution of the European Union' (1996) 112 L.Q.R. 95; A. Arnull, 'The European Court and Judicial Objectivity: A Reply to Professor Hartley' (1996) 112 L.Q.R. 411; and T. Tridimas, 'The Court of Justice and Judicial Activism' (1996) 21 E.L.Rev. 199. More generally see Miguel Poiares Maduro, We the Court: The European Court of Justice and the European Economic Constitution.

71 'Constitutionalizing Adjudication under the European Convention on Human Rights' (2003) 23 O.J.L.S. 405. See too A McHarg, 'Reconciling Human Rights and the Public Interest: Conceptual Problems and Doctrinal Uncertainty in the Jurisprudence of the European Court of Human Rights' (1999) 62 M.L.R. 671. The European Court will become even more of a constitutional body once the reforms envisaged by Protocol 14 to the European Convention kick in, a development which will delight the current Swiss President, Judge Wildhaber. See Luzius Wildhaber, 'A constitutional future for the European Court of Human Rights?' (2002) 23 H.R.L.J. 161. More generally see Steven Greer, 'Protocol 14 and the Future of the European Court of Human Rights' [2005] P.L. 83.

72 Unless they exploit their position so as to gain an advantage over a personal adversary: compare $A$ v $U K$ (2002) 36 E.H.R.R. 917 with Cordova v Italy (App Nos 40877/98 and 45649/99; 30 January 2003).

73 McGonnell v UK (2000) 30 E.H.R.R. 289. 
one can sit in the British Parliament unless he or she is prepared to swear personal allegiance to the Queen. ${ }^{74}$ That, surely, must be an aberration?

\section{Suggestions for How Judges Should Reform the UK Constitution}

So courts elsewhere have managed to develop constitutions quite significantly. This final section of the article makes a number of suggestions as to how UK judges should amend the British constitution - without the need for Parliamentary or governmental approval. These changes would create a more 'constitutionalised' state, meaning that the distribution and exercise of power would be controlled in a more consistent and principled fashion and that people would be left with a greater sense of being citizens of the world rather than of one small corner of it, Within the last century British judges have been unnecessarily timid in the constitutional field. ${ }^{75}$ The time has come for them to be more assertive. ${ }^{76}$

First, British judges should resurrect and develop the concept of 'constitutional rights'. A few judges did flirt with this idea in pre-Human Rights Act days, in cases like Leech, Witham and Simms. ${ }^{77}$ Now that that Act has embedded most of the Convention rights in our domestic law the time seems to me to be riper than ever for the enunciation of rights unenumerated in that Act. Such a position is supported by at least two former Law Lords, ${ }^{78}$ and also by the Cambridge scholar Mark Elliott. ${ }^{79}$

74 McGuinness v UK (App. 39511/98; decision of 8 June 1999). Cf. Buscarini v San Marino (2000) 30 E.H.R.R. 208.

75 See, generally, I. Harden and N. Lewis, The Noble Lie: The British Constitution and the Rule of Law. The claim that judges have been too timid in the specific field of judicial review is a different (and less defensible) claim; see, e.g. the comments by Lord Bingham in relation to Will Hutton's criticism of the judges' timidity, in 'The Courts and the Constitution', n.22 above, pp.231-4.

76 At the end of her piece on the House of Lords' decision in the Northern Irish case of Robinson v Secretary of State for Northern Ireland [2002] N.I. 390, Brigid Hadfield proclaims that 'Judicial reserve or caution is justified no longer': 'Does the Devolved Northern Ireland Need an Independent Judicial Arbiter?' in Nicholas Bamforth and Peter Leyland (eds.), Public Law in a Multi-Layered Constitution, ch.6, at p.156.

77 E.g. $R$ v Secretary of State for the Home Department, ex parte Leech [1994] Q.B $198 ; R$ v Lord Chancellor, Ex parte Witham [1997] 1 W.L.R. 104; $R$ v Secretary of State for the Home Department, ex parte Pierson [1998] A.C. 539; $R$ v Secretary of State for the Home Department, ex parte Simms [2000] 2 A.C. 115 at 131 (per Lord Hoffmann, who spoke of 'fundamental principles of human rights'); $R$ (Daly) v Secretary of State for the Home Department [2001] 2 A.C. 532; $R$ (ProLife Alliance) v BBC [2002] 2 All E.R. 756 at 773 (per Laws L.J.); Cullen v Chief Constable of the RUC [2003] 1 W.L.R. 1763, where Lord Millett described the right of access to a solicitor as a 'quasi-constitutional right'. See generally J. Jowell, 'Beyond the Rule of Law: Towards Constitutional Judicial Review' [2000] P.L. 671 and David Feldman (ed.), English Public Law pp.345-6.

78 Lord Steyn, 'Democracy Through Law' [2002] E.H.R.L.R. 723, where he states (at p.731): 'The importance of the development of constitutional rights has not come to an end with the advent of the Human Rights Act' and concludes (at p.734) that England, though inching towards it, cannot yet be described as a constitutional state. Also Lord Cooke, 'The Road Ahead for the Common Law' (2004) 53 I.C.L.Q. 273, where he asserts (at p.278): ‘. . in a liberal democracy there must be a bottom line of minority rights, certainly sometimes difficult to define, which 
Unfortunately, as I tried to indicate in the memorial lecture for Stephen Livingstone earlier this year, ${ }^{80}$ Britain's Law Lords have been unwilling to go beyond Convention rights by affirming the existence of additional rights under the common law. In particular they failed to do so in the Northern Irish case of Cullen, ${ }^{81}$ where a person held in custody was, in defiance of the rules, denied access to a solicitor at certain times. By 3 to 2 (with Lords Bingham and Steyn dissenting) the Lords refused to award any compensation for this breach of rights. Very regrettably, just a month ago the House set its face more firmly than ever against the idea of developing the concept of constitutional rights: in Watkins v Home Office $e^{82}$ they held that if prison officers maliciously interfere with a prisoner's correspondence with his solicitor, they will not be liable to pay compensation if no actual loss has been suffered by the prisoner. Lord Bingham seemed to go back on what he said in Cullen and joined Lord Rodger in claiming that the fact that the Human Rights Act was now in force was a further reason for not developing the concept of constitutional rights. With respect, I think that is misguided. ${ }^{83}$ There is surely much more to rights under the constitution than the concept of human rights? In my view the three key constitutional rights which judges should immediately develop, and provide compensation for if breached, are the right to access to justice, ${ }^{84}$ the right to equality ${ }^{85}$ and the right to fairness in decision-making. ${ }^{86}$

My second suggested reform is that judges should develop the idea of positive state duties as the corollary of constitutional rights. They should steal a march on their Strasbourg colleagues in this regard, for the latter have been a bit hesitant in fashioning duties out of Articles in the European Convention. ${ }^{87}$ To some extent British judges have already developed

cannot be crossed without a legal revolution. The legislative and judicial functions are complementary; the supremacism of either has no place'. See too Lord Cook's Hamlyn Lectures for 1996, Turning Points of the Common Law. Before being appointed a peer, Lord Cooke was President of New Zealand's Court of Appeal. He sat occasionally in the Appellate Committee of the House of Lords not as a Lord of Appeal but as a peer who had previously held high judicial office.

79 'Embracing “Constitutional” Legislation: Towards Fundamental Law?' (2003) 54 N.I.L.Q. 25. See n.4 above.

80 Safe in Their Hands? The Law Lords and Human Rights (2006) 26 L.S. (forthcoming).

81 Cullen v Chief Constable of the RUC [2003] 1 W.L.R. 1763.

82 [2006] 2 All E.R. 353.

83 Our law already allows exemplary damages to be awarded when there has been oppressive, arbitrary or unconstitutional action by servants of the government: see Kuddus v Chief Constable of Leicestershire Constabulary [2002] 2 A.C. 122.

84 A starting point could be $R$ v Lord Chancellor, ex parte Witham [1997] 2 All E.R. 778.

85 Maybe a seed has been sown in A v Secretary of State for the Home Department [2005] 2 A.C. 68. See Sandra Fredman, 'From Deference to Democracy: The Role of Equality under the Human Rights Act 1998' (2006) 122 L.Q.R. 53.

86 See, most recently, $R$ (Smith) v Parole Board [2005] 1 W.L.R. 350 and, on the idea of 'good administration', $R$ (Nadarajah) v Home Secretary [2005] EWCA Civ. 1363.

87 Alastair Mowbray, The Development of Positive Obligations under the European Convention on Human Rights by the European Court of Human Rights. 
positive duties based on Article $2,{ }^{88}$ but there is a lot more they could do visà-vis, say, Articles 3 and 8 . For instance, if women have the right not to be subjected to domestic violence, should the state not be under a duty to provide refuges and other support facilities for abused women? And if we all have the right to be free from degrading treatment and personally secure, should judges not oblige the state to protect us against environmental degradation? The Indian Supreme Court has been severely criticised for inappropriate meddling in environmental issues, ${ }^{89}$ but in Britain the courts have been almost completely silent in the area.

Thirdly, judges should assert more forcefully their power to review the exercise of Crown prerogatives. There is no need to follow Tomkins in calling for a Prerogative (Abolition) Act. ${ }^{90}$ The decision in the GCHQ case, back in $1984,{ }^{91}$ was clearly a missed opportunity to subject the government more meaningfully to the rule of law. Although the European Court of Human Rights agreed that considerations of national security justified the British government's ban on trade unions at the site in question, ${ }^{92}$ the House of Lords could surely have been more interventionist in assessing the strength of the government's claim. True, later cases have shown that the courts are sometimes willing to intervene on other prerogative powers, such as the power to issue passports, ${ }^{93}$ to grant pardons ${ }^{94}$ or to render diplomatic assistance to a British subject who is suffering violation of a fundamental human right as the result of the conduct of the authorities of a foreign state. ${ }^{95}$ Given recent controversies over peerages for donors of money, maybe judges will soon get the opportunity to decide whether certain honours have been legally bestowed? And it is not inconceivable that the lawfulness of resort to foreign military action will sooner or later be justiciable, whether or not Parliamentary approval is also required. ${ }^{96}$ But Britain still awaits its equivalent to the Watergate case in America. ${ }^{97}$ There the Supreme Court recognised that the President does have the right to keep many conversations confidential, but it nevertheless held that the duty to ensure fairness in a criminal trial overrides that privilege. Richard Nixon resigned as President

${ }^{88} R$ (Amin) v Secretary of State for the Home Department [2004] 1 A.C. 653; $R$ (Middleton) v West Somerset Coroner [2004] 2 All E.R. 465; $R$ (Sacker) v West Yorkshire Coroner [2004] 2 A.C. 182; $R$ (Takoushis) v HM Coroner for Inner North London [2005] EWCA Civ. 1440; $R(D)$ v Secretary of State for the Home Department [2006] EWCA Civ. 143.

89 Shubhankar Dam, "Polluting Environment, Polluting Constitution: Is a "Polluted" Constitution Worse than a Polluted Environment?' (2005) 17 J. Envtl. L. 383.

90 Our Republican Constitution, p.133.

91 Council of Civil Service Unions v Minister for the Civil Service [1985] 1 A.C. 374.

92 Council of Civil Service Unions v UK (1987) 50 D.R. 228.

$93 R$ v Secretary of State for Foreign and Commonwealth Affairs, ex parte Everett [1989] 1 All E.R. 655.

$94 \quad R$ v Secretary of State for the Home Department, ex parte Bentley [1993] 4 All E.R. 443.

$95 R$ (Abbasi) v Secretary of State for Foreign and Commonwealth Affairs [2002] EWCA Civ. 1598.

96 The Armed Forces (Parliamentary Approval for Participation in Armed Conflict) Bill - a private member's measure - is currently before Parliament.

97 US v Nixon (1974) 418 U.S. 683. 
just two weeks after the Supreme Court's decision. ${ }^{98}$ The closest Britain has come to this degree of scrutiny of executive privilege was probably during the recent Hutton Inquiry into the death of David Kelly. ${ }^{99}$ The outcome of that inquiry is for present purposes irrelevant, but what $i s$ worth noting is the irony that a Law Lord who was not presiding in a court and who could not make any judgment as to civil or criminal liability was nevertheless supplied with more information than he would have been given if he had been so presiding - he even got to see Alastair Campbell's private diary!

My fourth suggestion is that the doctrine which allows foreign governments to claim sovereign immunity when sued in the United Kingdom needs to be restricted. The primacy of customary international law should be recognised. For example, people who are the victims of state-sponsored torture abroad should be able to sue the foreign governments in British courts ${ }^{100}$ and, if they win, they should be able to enforce the judgment against the foreign government's assets in this country. As it happens, an appeal dealing with this point has just concluded in the House of Lords. ${ }^{101}$ When they are writing their judgments let's hope the Law Lords in that case make as good a use of international law as they did in the two Belmarsh cases ${ }^{102}$ and in the Pinochet case some years ago. ${ }^{103}$

Fifthly, as I argued in the Livingstone lecture, ${ }^{104}$ judges should put a severe dent in the constitutional principle that international treaties ratified by the government have no effect within our national legal system unless they have been expressly incorporated into our law. ${ }^{105}$ In the Northern Irish case of McKerr, two years ago, ${ }^{106}$ Lord Steyn called for this dualist approach to international law to be reconsidered. A majority of judges in the High Court of Australia came to the same conclusion nearly 10 years before that, ${ }^{107}$ though it is fair to say that the idea has not since taken root there and, apart from its work on the rights of indigenous peoples, ${ }^{108}$ the Australian Court has a record that is probably worse than that of the House of Lords in implying constitutional rights. ${ }^{109}$ Of course allowing treaties to have an effect does not

98 The court announced its decision on 24 July 1974; the President resigned on 8 August 1974.

99 www.the-hutton-inquiry.org.uk.

100 Contrary to the outcome in Al-Adsani v Kuwait (1996) 107 I.L.R. 536.

101 Jones v Ministry of the Interior of Saudi Arabia. For the Court of Appeal decision see [2004] EWCA Civ. 1394.

102 See n.30 and n.31 above.

${ }^{103} R \mathrm{v}$ Bow Street Metropolitan Stipendiary Magistrate, ex parte Pinochet Ugarte (No. 3) [2000] 1 A.C. 147.

104 See n.80 above.

105 This is the so-called principle of dualism. It was approved by the House of Lords in what is known as The International Tin Council case, i.e., J H Rayner (Mincing Lane) Limited v Department of Trade and Industry [1990] 2 A.C. 418.

106 [2004] 1 A.C. 807.

107 Minister for Immigration and Ethnic Affairs v Teoh (1995) 183 C.L.R. 273.

108 Notably in Mabo v Queensland (No 2) (1992) 175 C.L.R. 1. See, generally, Haig Patalan, Judging Democracy: The New Politics of the High Court of Australia, ch.5.

109 David Kinley (ed.), Human Rights in Australian Law, pp.36-43 and Patalan, n.108 above, ch.3. But, unlike the House of Lords, the High Court retains the jurisdiction to declare Acts to be unconstitutional. 
mean that they have to become binding: judges should develop a rebuttable presumption that national law must be read in a way which makes it consistent with ratified treaties unless there are very strong policy reasons why an inconsistency should be preserved. This would go further than the principle of statutory construction which is currently applied, namely, that statutes are to be read as consistent with ratified treaties only if they are reasonably capable of bearing such a meaning. ${ }^{110}$

Sixthly, judges should expand still further the sources they are prepared to look at before they decide cases. At present they very largely restrict themselves to 'legal' sources, ignoring information which is primarily economic or sociological in nature. They should, in short, accept Americanstyle 'Brandeis briefs'.111 Provided limits are placed on the size of such documents, and that resort to oral argument is more time-limited, as it is in the Washington and Strasbourg courts, there is no reason to believe that proceedings in British courts would be unduly lengthened as a result of this reform.

Seventhly, and this links to the point just made, judges need to commit themselves to a much more contextual approach to statutory interpretation, one that goes beyond the requirement in section 3 of the Human Rights Act 1998 that legislation must be read and given effect in a way which is compatible with Convention rights 'so far as it is possible to do so'. ${ }^{112}$ An archetypal example of this not happening is the recent case of $R \mathrm{v} J,{ }^{113}$ where a man in his thirties who had allegedly had repeated sex with a 13-year-old girl was charged with indecent assault on a woman, contrary to section 14 of the Sexual Offences Act 1956. He was not charged with having unlawful intercourse with a girl under 16 , contrary to section 6 , because a prosecution for that offence had to be brought within 12 months and this one had not been. ${ }^{114}$ The four male Law Lords allowed the defendant's appeal against conviction, on the basis that Parliament could have had no possible purpose in prohibiting a prosecution under section 6 after the lapse of 12 months if exactly the same conduct could then be prosecuted under section $14 .{ }^{115}$ Lord Bingham said that any other result was 'impossible' and Lord Steyn thought the conclusion was 'inescapable'. Yet Lady Hale, who is so far the only woman to have been appointed to our top court, strongly dissented. For her the only unfairness in the case was that being done by her fellow judges to the young girl and the many like her. ${ }^{116}$ Lady Hale said the Sexual Offences Act was a mess when it was enacted and was an ever greater mess when it

110 Garland v British Rail Engineering Ltd [1983] 2 A.C. 751. See the discussion in Murray Hunt, Using Human Rights Law in English Courts, pp.76-88.

111 Louis Brandeis (later a justice of the US Supreme Court) first submitted a collection of medical and sociological evidence in Muller v Oregon (1908) 208 U.S. 412.

112 S.3 was used quite imaginatively by the House of Lords in $R$ v $A$ [2002] 1 A.C. 45 and Ghaidan v Godin-Mendoza [2004] 2 A.C. 557.

113 [2005] 1 A.C. 562. For comments see [2005] P.L. 193

114 S.37(2) of, and para.10(a) of Sch.2 to, the 1956 Act. The time limit was abolished from 1 May 2004 by the Sexual Offences Act 2003.

115 Especially, they added, as the maximum penalty for both offences was the same 10 years in prison.

116 ibid., para.69. 
was amended. It simply was not possible to discern within it a Parliamentary intention along the lines suggested by her brethren. As she put it: 'Although we do have to try to make sense of the words Parliament has used, we do not have to supply Parliament with the thinking that it never did and the words that it never used.' 117 I fervently hope that Lady Hale's approach to statutory interpretation is the one that begins to prevail. As we all know, context is everything.

My eighth point is that senior judges should begin to exercise the power to overrule precedents for the future only. At present, when they overrule a precedent, one of the parties to the case at hand bears the consequences of the change to the law, even though that party might have thought the 'old' law was perfectly good and have based his or her conduct on it. Prospective overruling avoids this sense of injustice, allowing the case at hand to be decided in accordance with the pre-existing law but sending out a message to future litigants that for them the law has changed. The Federal Constitutional Court of Germany has given itself this power, where practical reasons demand it. ${ }^{118}$ Seven Law Lords asserted it for themselves in the Spectrum Plus case last year, but they opted not to make use of it on the facts before them. ${ }^{119}$ There seems to me to be particular scope for prospective overruling in criminal cases, where it is surely unjust that a defendant can find him - or herself punished for falling foul of a new interpretation of the law that did not exist at the time the alleged crime was committed. ${ }^{120}$

Ninthly, judges should be prepared to consider abstract legal questions, the so-called actio popularis. They are edging towards doing this, as is evident from cases such as the one taken by The Guardian against the statutory ban on campaigning to abolish the monarchy ${ }^{121}$ or the one brought by the Family Planning Association here in Belfast against the uncertainty inherent in Northern Ireland's abortion laws. ${ }^{122}$ If judges did a lot more of this kind of judging they would help to clarify legal principles and in the process greatly enhance the rule of law.

Finally, and most radically, our top judges should claim for themselves the power to declare Acts of Parliament to be unconstitutional. We should never

117 ibid., para.89.

118 Lars Mammen, 'A Short Note on the German Federal Constitutional Court and its Power to Review Legislation' [2001] E.H.R.L.R. 433.

119 Re Spectrum Plus Ltd [2005] 3 W.L.R. 58.

120 Art.7 of the European Convention on Human Rights supposedly prohibits retrospective criminal law, yet the European Court still managed to find no breach of this when the House of Lords upheld the conviction of a man for raping his wife at a time when such behaviour was not thought to be criminal: $R$ v $R$ [1992] 1 A.C. 599 and $C R$ v $U K$ (1996) 21 E.H.R.R. 363. See, generally, Michael Zander, The Law-Making Process (6 $6^{\text {th }}$ ed., 2004), pp.397-403.

$121 R$ (Rusbridger) v Attorney-General [2004] 1 A.C. 357. The bar derives from s. 3 of the Treason Act 1848. See too $R$ v Secretary of State for the Home Department, ex parte Salem [1999] A.C. 450, where the Lords said they had a discretion (not exercised in the case) to hear a point of public law of public interest, notwithstanding that the facts giving rise to the dispute have changed in favour of the party who initiated the proceedings.

122 Re Family Planning Association for Northern Ireland's Application [2005] N.I. 188. See too Re E's Application [2003] N.I.J.B. 288. 
forget that the doctrine of Parliamentary sovereignty, which supposedly lies at the base of our constitution, is itself a construct of the common law. ${ }^{123}$ The current Attorney General, Lord Goldsmith, expressly stated this in an answer to a Parliamentary question asked by Lord Lester of Herne Hill two years ago. ${ }^{124}$ Judges can therefore, if so inclined, modify the doctrine. This is what the Law Lords were invited to do last year when there was a challenge by the Countryside Alliance to the constitutionality of the Hunting Act 2004, passed by the House of Commons without the consent of the second Chamber. ${ }^{125}$ While all nine Law Lords held the Act to be valid, because it was passed in accordance with the Parliament Act of 1949, which in turn had been passed in accordance with the Parliament Act of 1911, five Law Lords expressly stated $^{126}$ that if the House of Commons alone were to try to delete from the 1911 Act the section which prevents it from extending the maximum permitted life of a Parliament beyond five years, that would not be a constitutional Act. Lord Steyn went further, suggesting that courts should be able to invalidate Acts which seek to abolish any fundamental feature of our constitution, such as the right of access to judicial review. ${ }^{127}$

In 2004, when the government was pushing another of its Asylum and Immigration Bills through Parliament, it inserted a provision ${ }^{128}$ which would have ousted the jurisdiction of the courts to hear challenges against decisions of the immigration appeal tribunals. There was a huge outcry, not least from Lord Woolf, the Lord Chief Justice. ${ }^{129}$ Eventually the clause was dropped. But if Parliament had gone ahead and enacted it, would courts have held it to be unconstitutional? I very much hope so. Similarly, if in April 2006 the government had not climbed down on its Legislative and Regulatory Reform Bill, under which ministers could have done all sorts of things that only an elected Parliament should be able to do, I like to think that, had a challenge been raised in the courts against a government measure taken under the Act, judges would have declared it too to be unconstitutional. As Gibbon noted in The Decline and Fall of the Roman Empire, published around the same time as the American Constitution: 'The principles of a free constitution are irrecoverably lost, when the legislative power is nominated by the

123 See, e.g. H.W.R. Wade, 'The Legal Basis of Sovereignty' (1955) 13 C.L.J. 172.

124 Hansard (H.L.), 31 March 2004, col. W.A. 160.

$125 R$ (Jackson) v Attorney General [2006] 1 A.C. 262. For a comment see Michael Plaxton, 'The Concept of Legislation: Jackson v Her Majesty's Attorney General' (2006) 69 M.L.R. 249.

126 Lord Nicholls (para.59), Lord Steyn (para.79), Lord Hope (para.122), Lady Hale (para.164) and Lord Carswell (para.175).

127 ibid., para.102 ('In exceptional circumstances involving an attempt to abolish judicial review or the ordinary role of the courts, the Appellate Committee of the House of Lords or a new Supreme Court may have to consider whether this is a constitutional fundamental which even a sovereign Parliament acting at the behest of a complaisant House of Commons cannot abolish'.) For extra-judicial comments by Lord Steyn in the area of constitutional law see 'Democracy Through Law' [2002] E.H.R.L.R. 723.

128 Clause 14

129 'the rule of Law and a Change in the Constitiution', Squire Centenary Lecture, Cambridge, 3 March 2004, available on the website of the Department for Constitutional Affairs. See too, 'Lord Steyn's Comments from the Lester and Pannick Book Launch’ [2004] J.R. 107. 
executive'. ${ }^{130}$ Or, as the US Supreme Court put it in 1966, 'Where rights secured by the Constitution are involved, there can be no rule making or legislation which would abrogate them'. ${ }^{131}$

130 The Decline and fall of the Roman Empire (1776-88), ch.3.

131 Miranda v Arizona (1966) 384 U.S. 436 at 491. 